\title{
THE INTERNATIONAL COURT OF JUSTICE: AMENDMENT OF THE STATUTE AND NEW INTERNATIONAL LAW
}

\author{
J. F. O'CONNOR*
}

The International Court of Justice, in accordance with its statutory authority, ${ }^{1}$ has for the first time submitted to the SecretaryGeneral of the United Nations a proposal to amend its statute. The supporting memorandum ${ }^{2}$ explains the Court's proposed amendment to article 22, which now provides that the seat of the Court shall be established at The Hague. Since 1966 the Government of the Netherlands has had under consideration a proposal that a new building be erected for the Court, and the Court does not want to confine the choice of location to The Hague itself. Even another location in the Netherlands outside the municipal limits of The Hague could not be contemplated unless the statute of the Court is amended.

It is clear that the proposed change is not entirely due to the town planning situation at The Hague. The memorandum sets forth "other reasons" and in particular that an amendment is desirable because the particularity of the provision that "the Seat of the Court shall be established at The Hague" is invidious. No other principal organ of the U.N. and none of the Specialized Agencies, or the IAEA, is compelled by its basic instrument to maintain its seat in a designated place.

The reason for this particular designation in the basic instrument of the Court is primarily historical. The Court's predecessor, the Permanent Court of International Justice, was subject to the same restriction. ${ }^{3}$ The location of the Permanent Court at The Hague in 1922 is understandable. The Hague had become associated with the judicial settlement of international disputes through the work of the Permanent Court of Arbitration established there by The Hague Conventions for the Pacific Settlement of International Disputes of 1899 and 1907. Also, the emotive association of The Hague with peace since the Conferences of 1899 and 1907 was a potent factor in the post

\footnotetext{
* Lecturer in Law (National University of Ireland) at University College Cork; LL.B. 1962, London; called to English Bar by Lincoln's Inn, 1965; LL.M. 1967, London.

1. I.C.J. STAT. art. 70.

2. U.N. Doc. A/7591, A/7591/Add. 1 (1969), [1968-1969] I.C.J.Y.B. 108.

3. P.C.I.J.STAT. art. 22.
} 
World War I atmosphere. In addition, the desirability of separating the political functions of the League of Nations, based in Geneva, and the judicial functions of the Court, contributed to the decision to locate the Permanent Court of International Justice at The Hague.

Apart from the practical convenience of locating the new International Court of Justice in the building occupied by its predecessor, there was no reason why the new Court should not have been instituted in a new seat. The decision to establish a new Court, rather than to adapt the existing Permanent Court, was taken after considerable deliberation ${ }^{4}$ with political factors contributing largely to the decision. ${ }^{5}$ The emphasis was on the new Court forming an integral part of the United Nations, ${ }^{6}$ in contrast to the formal separation of the Permanent Court and the League, which could have led naturally to a decision to establish the new Court elsewhere than at The Hague. However, there was a marked desire to preserve legal continuity with the old Court, and in the charter itself the nexus is recognized in article 92 which states that the Statute of the International Court is based upon the Statute of the Permanent Court.

The close similarity in statutes, the organization and the continuance of the new Court in the seat of the old have all contributed to the close identification of the two institutions, and the judges of the International Court have reinforced this identification by emphasizing the continuity in jurisprudence of the Courts. ${ }^{7}$ These factors and the laudable desire to preserve the independence of the International Court as a judicial organ have to some extent obscured the essential fact that the new Court is a principal organ of a political institution.

The reasons given for the proposed change are open to question. Indeed, as Professor D.H.N. Johnson observed in a preliminary comment on the proposal, 8 it is difficult, with the information presently available, to tell what the Court really has in mind. It is clear, however, that the Court recognizes the fundamental changes that have

4. The question was discussed in Subcommittee IV/1/A San Francisco Conference 1945, and the reasons for the decision were given in the Report of the Subcommittee to Commission IV. Doc. 913, IV/1/74(1), 13 U.N.C.I.O. Docs. 381 (1945).

5. 1 S. Rosenne, The Law and Practice of the International Court 36 (1965).

6. U.N. CharTER art. 7:92.

7. For examples see Interpretation of Peace Treaties with Bulgaria, Hungary and Romania, [1950] I.C.J. 65, 71-72; id. at 233 (dissenting opinion of Read, J.); Corfu Channel Case (Merits), [1949] I.C.J. 4, 24; H. LaUterpacht, The Development of International LaW gY the INTERNATIONAL COURT 11 (1958).

8. Johnson, Recent Developments in the International Court of Justice, 33 MODERN L. REv. $53,61(1970)$. 
occurred in the framework of international society since the institution of the Permanent Court. The Court's announcement includes the following paragraph:

Since 1922, changes in world conditions have affected the relative significance for the operations of the International Court of Justice, of The Hague and of other places. The special qualities attached to The Hague in 1922 are less distinctive now, and the importance of other places as legal centers has been enhanced. 9

The emphasis here on "other" places seems to suggest that the Court is not simply contemplating a minor move outside The Hague, but preparing the ground for possible abandonment of Europe altogether as a center for its activities. The symbolic significance which such a removal would have is aptly summarized by Professor Johnson:

What could more effectively symbolise, for instance, the substitution of a "new international law" for the system of European origin that at present exists than the eviction of the highest international tribunal from the homeland of Grotius? Symbols are not without importance, and this seemingly innocent proposal may conceal an intention to bring the administration of international justice down into the political arena..$^{10}$

A simple explanation for the proposal is that the Court wishes formally to recognize the emergence of the many new subjects of international law in Africa and Asia." There is no evidence that the judges of the Court themselves wish to leave Europe, and it is diffcult to suggest an alternative seat which would receive widespread immediate acceptance. Apart, therefore, from the desirability of marking the universality of the Court and bringing the designation of its seat into line with the other organs of the U.N., the proposed amendment at this time seems to have little significance.

However, any suggestion of a possible rejection of the "European" basis of international law and a "descent" by the Court into the political arena raises serious questions for the future of the Court and the fragile hopes for a strengthening and extension of the system of judicial settlement of international disputes. Such a suggestion considered against the background of recent events touching the Court acquires added significance; it is, therefore, not surprising that

9. [1968-1969]1.C.J.Y.B. 109.

10. Johnson, 33 MODERN L. Rev., supra note 8, at 61.

11. It has been suggested that the remoteness of the Court from non-European countries may account, to some degree, for the lack of recourse to the Court by African and Asian States. See Anand, Role of the "New" Asian African Countries in the Present International Legal Order. 56 Am. J. InT'L L. 383, 403 \& nn. 95-96 (1962). 
when the proposal came before the General Assembly the opportunity was taken to initiate a review of the role of the Court generally. ${ }^{12}$

The 1966 judgment on South West Africa, the last election of judges, and, most recently, the Advisory Opinion on the Consequences for States of the Continued Presence of South Africa in Namibia, delivered in June, 1971, have created an unprecedented crisis of confidence in the Court. In such a situation the proposed amendment of article 22, while perhaps useful for minor practical or symbolic reasons, will seem to many to be much less important for the future of the Court than other possible and more far reaching amendments. One such amendment, a reformulation of the "Sources" of international law contained in article 38 is suggested below in this article, and can be achieved without proposing an idealistic and impractical "new" source of international law. More important, it can be achieved with an acknowledgement of the political function of the Court while preserving its judicial independence. One of the greatest defects of the present statute is that, while it stresses in article 1 that the Court is the principal judicial organ of the United Nations, it does not, in article 38 or elsewhere, make clear that the international law which the Court must apply today includes international custom as collectively generated in the United Nations and other international bodies. An explicit acceptance of this source of international law in the statute would enable the Court to perform its necessary political role in the true sense without descending into "mere" politics and without compromising its judicial function. It would also help to minimize the undesirable emphasis on the nationality and political affiliations of individuals in the elections of judges of the Court.

\section{The United Nations and "New" International Law}

The rapid and dramatic changes in the composition and character of international society and the difficulties which these changes have created for the evolution of international law have been noted by

12. The General Assembly decided on Dec. 8,1970 , to postpone consideration of the proposal until the 26th (present) Session. By Resolution 2723 (XXV), of Dec. 15, 1970, states were invited to submit by July I, 1971, views and suggestions concerning the role of the Court on the basis of a questionnaire to be prepared by the Secretary-General. The date for submissions was extended to July 1, 1972, and the proposal to amend article 22 and the review of the role of the Court will not now be considered before next session. 
modern writers. ${ }^{13}$ The small club of European states who shared generally similar political, moral and legal ideas has grown into an international community of 130 sovereign states with a wide diversity of political, social and economic systems, subjecting international law to a number of dilemmas: it continues to operate with concepts which originated and developed in a totally different environment; unlike municipal legal systems, there is no legislature to reform and up-date the law to accord with developments in international society; and unlike municipal legal systems, international law-determining agencies-foremost among these, the International Court of Justice-are not assisted in their function of developing the law to accord with developments in international society because the society in question lacks the homogeneity generally found within states.

The general structural framework within which international law operates is further complicated by certain features of organized international society. The United Nations, pre-eminent in that society, reflects the changed world order. Its origin is closely linked to the era of international relations marked by hegemonial, political power. ${ }^{14}$ Since the U.N.'s foundation, however, the then already crumbling old order has rapidly disintegrated, making attempts to describe international law in traditional terms increasingly difficult. Also, the sociopolitical basis on which international relations rested has been largely rejected by newly emerged states, and some traditional rules of international law are being directly challenged..$^{15}$

The new states, many of whom are included in the new world bloc-the so-called "Third World"16 _tend to regard many of the

13. W. Friedmann, The Changing Structure of International Law (1964); C. De Visscher, Theory and Reality in Public International Law 162-63, 404-06 (rev. ed. P. Corbett transl. 1968).

14. The Moscow Declaration, Oct. 30, 1943, confirmed the agreement of the United States, Soviet Union, United Kingdom and China, to establish such a world organization. At the Dumbarton Oaks Conference it was assumed that agreement between these great powers was essential to the success of the United Nations. L. Goodrich \& A. Simons, THE UNiTED Nations and the Maintenance of International Peace and SeCurity 11 - 12 (1955).

15. For example, a particularly controversial area is the problem of the "minimum standard" and the standard of national treatment in cases of expropriation of foreign property interests. See W. Friedmann, supra note 13, at 318-20; G. SchWARZENBERger, Foreign INVESTMENTS AND INTERNATIONAL LAW (1969) (especially pages 7-11) (discussing the problem). See generally G. White, Nationalisation OF ForEign Property (1961).

16. African and Asian States predominate in membership of the Third World, but it is not an exclusively Afro-Asian or non-white alliance. Predominantly white states in Europe (e.g., Yugoslavia) and South American states (e.g. Argentina and Uruguay) may also be considered part of the Third World. See Preiswerk, Race and Colour in International Relations, in 1970 Y.B. WORLD AFF. 63. 
rules in modern international law as the exclusive work of five or six great powers. Furthermore, they consider that a number of these rules owe their origins to duress or illegality-in particular, those rules which justify racial discrimination, conquest, annexation and colonization. ${ }^{17}$

It thus becomes easier to understand the fears of a broad range of new States in three continents, who dispute the legitimacy of certain rules of international law, not only because they were adopted without them, but also because they do not seem to them to correspond to their legitimate interests, to their essential needs on emerging from the colonialist epoch, nor, finally, to that ideal of justice and equity to which the international community, to which they have at long last been admitted, aspires. What the Third World wishes to substitute for certain legal norms now in force are other norms profoundly imbued with the sense of natural justice, morality and humane ideals. ${ }^{18}$

Ironically, the great powers who once dictated the content of international law and who rejected proposals to confer power on the General Assembly to legislate ${ }^{19}$ have themselves largely accelerated changes which may militate against them. The ideological conflict of the "Super Powers" and their concomitant political postures have involved them with small and even mini-states; the influence of medium and small powers has grown accordingly. ${ }^{20}$ In the United Nations, the ideological conflict having largely stultified the original concept of the influence of the Security Council, the power and influence of the General Assembly has increased. This influence extends into the sphere of international law.

In particular, the "new" international law received a powerful impetus from the changing composition and character of the General Assembly. Judge Alvarez saw new international law, which he termed "the law of social interdependence," as the outcome of the realities of international life and the product of the "juridical conscience of the nations." ${ }^{21}$ The General Assembly pre-eminently provides a voice

17. Barcelona Traction, Light and Power Co. Case, [1970] I.C.J. 309.

18. Id. at 310 .

19. One such proposal at the San Francisco Conference (by the Phillipines) is referred to by Judge Ammoun in his Separate Opinion in the Barcelona Case, [1970] I.C.J. 302.

20. Professor R.L. Rothstein in a recent work examines the paradox that while the relative strength of small states (measured in traditional capabilities) has declined, their status and actual power appear to have increased. R. RothSTEIN, ALLIANCES AND SMALL Powers (1968).

21. Advisory Opinion on Admission of a State to the United Nations (Charter, Art. 4), [1947-48] I.C.J. 69 (opinion of Alvarez, J.). "New international law" is mainly associated with the late Judge Alvarez, whose advocacy of it commenced after World War I and continued after his election to the International Court in 1946. 
for this "juridical conscience of the nations." At no time in the history of the world has there been such a forum for the expression of near-universal views on a wide range of issues. The General Assembly, for example, in the following resolutions has declared the collective voice of the nations of the world:

Universal Declaration of Human Rights; $; 2$

Declaration on the Granting of Independence to Colonial Countries and Peoples; ${ }^{23}$

Resolution on Permanent Sovereignty over Natural Resources; ${ }^{24}$

Declaration on the Elimination of All Forms of Racial Discrimination. ${ }^{25}$

It is not proposed here to elaborate on the above ${ }^{26}$ or to consider the legally binding effect, per se, of these "declaratory" resolutions of the General Assembly. ${ }^{27}$ What is clear, however, is that these and similar exercises in the international community are providing an ethical and political basis for new international law comparable to the Christian/European basis of traditional international law. The importance of this for the future of international law lies in the essential connection between law and the context in which it operates.

It is evident that municipal legal systems originate in and operate within political settlements. Formal constitutional provisions clothe these settlements with abstract and high-sounding principles; once accepted-a political accomplishment-the integrated and homogeneous nature of normal states permits constitutional machinery, in-

22. U.N. Doc. A/811 (adopted Dec. 10, 1948); G.A. Res. 217, U.N. Doc. A/810, at 71 (1948). The voting was 48 for, 0 against, 8 abstentions.

23. G.A. Res. 1514, 15 U.N. GAOR Supp. 16, at 66, U.N. Doc. A/4684 (adopted Dec. 14, 1960). The voting was 89 for, 0 against, 9 abstentions.

24. G.A. Res. 1803, 17 U.N. GAOR Supp. 17, at 15, U.N. Doc. A/5217 (adopted Dec. 14, 1962). The voting was 87 for, 2 against, 12 abstentions.

25. G.A. Res. 1904, 18 U.N. GAOR Supp. 15, at 35, U.N. Doc. A/5515 (adopted unanimously Nov. 20, 1963). This resolution was one of the precursors of the International Convention adopted by the General Assembly on Dec. 21, 1965, as annex to G.A. Res. 2106, 20 U.N. GAOR Supp. 14, at 47, U.N. Doc A/6014 (1965).

26. For convenient texts, notes and references to further works, see I. BrowNLIE, BASIC DOCUMENTS IN INTERNATIONAL LAW (1967).

27. See Sloan, The Binding Force of a Recommendation of the General Assembly of the U.N.. 25 BRIT. Y.B. INT'L L. I (1948). For a criticism of Sloan's view see Johnson, The Effect of Resolutions of the General Assembly of the U.N., 32 BRIT. Y.B. INT'L L. 97 (1955-56). See also Cheng, International Law in the U.N., 1954 Y.B. WORLD AFF. 170; and, for judicial views, see Advisory Opinion on S.W. Africa, Voting Procedure [1955] I.C.J. 67, 118-19 (opinion of Lauterpacht, J.); S.W. Africa Cases (Second Phase), [1966] I.C.J. 323, 432 (dissenting opinion of Jessup. J.). 
cluding the separation of legislative and judicial functions, to operate. The greater the degree of willing acceptance of the constitution in a state, with consequent stability of political institutions, the greater the emphasis which can be laid on the functional separation of Parliament, the Executive and the Courts. In time, this separation leads to the effective fiction that the law, and in particular the operation of the Courts, is "above" politics. The protected and privileged position often accorded to judges reinforces the fiction. Emphasis on fundamental rights and legal machinery for protection of the individual contributes to the "mystique" of the law as a superior order to the cynicism and opportunism of "mere" politics. ${ }^{28}$ The practical advantage of this idea is considerable and the beneficient effect of "the rule of law" thus achieved is undeniable.

But in practice municipal law performs a necessary political function by adverting to realities. Judges play a major part in adapting the law to changing social or political needs. ${ }^{29}$ Where cases raise, directly or indirectly, controversial political issues, judges are not absolved from their duty. Inevitably they must accept criticism that particular decisions were animated by political or social prejudice. ${ }^{30}$

The political basis of international law and the political function of its highest judicial organ, the International Court of Justice, is even more apparent. This is most clearly seen in the nomination and election of judges of the International Court.

The dissatisfaction with the system of nomination and election, which unduly emphasizes the political factors involved in the election of judges, has been increasing. ${ }^{31}$ Both in the Permanent Court and in the International Court the system was intended to protect the interests of the great powers, and presently it continues to do so to the extent of virtually guaranteeing that the permanent members of the Security Council will have their nationals on the Bench. However, the changes which have occurred in international society generally, and which are reflected in the General Assembly, are also reflected in the

28. In times of national crisis the political reality behind the law emerges clearly in the suspension of normal legal processes, the use of emergency powers, special courts, etc.

29. See generally W. FRIEDMANN, LEgal ThEORY ch. 32 (5th ed. 1967).

30. In the U.K., for example, the decision of the House of Lords in Rookes v. Bernard, [1964] A.C. 1129, provoked particularly strong criticism. Its effect on trade union activities was largely nullified, under union pressure, by the passing of The Trade Disputes Act 1965. The U.S. Supreme Court has also attracted widespread criticism for its deeisions on cases with sensitivc political and social implications, e.g., Baker v. Carr, 369 U.S. 186 (1962); Brown v. Board of Educ., 347 U.S. 483 (1954).

31. S. RoSENNE, supra note 5 , at 184-90. 
pattern of elections to the International Court.

In the last election, ${ }^{32}$ for example, the shadow of the Seventh Assembly of the Organization of African Union ${ }^{33}$ was evident. The Assembly had adopted a resolution demanding increased African representation on the Court which had only two African judges; subsequently all thirty-nine African states strongly supported the candidacy of M. Ignacio Pinto of Dahomey who was duly elected. This solidarity produced a Court in which the Third World, as a relatively cohesive block, is strongly represented. In addition to the three African judges, the Court now includes two judges from Asia, one from the Middle East, and two from South America. ${ }^{34}$

This is not an undesirable political development and provides evidence of the erosion of the once predominantly "European" character of the Court. This development is to be welcomed in an organ which, if it is to retain credibility, must reflect fairly the universality of its parent body. Unfortunately, the background to the election and the subsequent involvement of the Court in yet another South West Africa case may increase the tensions between "old" and "new" international law, and does increase the danger that the Court may not be permitted to realize its great potential in helping to resolve these tensions.

The emergence of a substantial group of judges with a new ideology of international law is a notable event in the history of the Court..$^{35}$ There have always been doctrinal differences among the judges-inevitable in a body of judges of different nationalities and legal systems. Also there have been "progressives" and "conservatives" on the Bench. In the past such labels could be applied to judges irrespective of their origin, and no doubt in the future the Court will

32. The normal election of 5 new ntembers was held on Oct. 27, 1969.

33. The Assembly was held in Addis Ababa, Sept., 1969.

34. Present regional representation is:

$\begin{array}{ll}\text { Western Europe } & 4 \text { (U.K., France, Spain, Sweden) } \\ \text { Eastern Europe } & 2 \text { (U.S.S.R., Poland) } \\ \text { North America } & 1 \text { (U.S.) } \\ \text { South America } & 2 \text { (Uruguay, Mexico) } \\ \text { Africa } & 3 \text { (Nigeria, Senegal, Dahomey) } \\ \text { Asia } & 2 \text { (Pakistan, Phillipines) } \\ \text { Middle East } & 1 \text { (Lebanon) }\end{array}$

35. Since 1946 the Eastern European Socialist bloc has been represented on the Court by at least two judges, and they generally present a common "ideological" view which differs sharply from the opinion of the non-socialist majority. Grzybowski, Socialist Judges in the International Court of Justice, 1964 DukE L.J. 536-49. Their effect as a group has not been significant. 
continue to draw individual progressive or conservative judges from all sides of the political ideological barriers. Until recently, however, it could be said that the majority of judges shared the same basic views on international law. This is no longer the case.

For some years a trend toward a polarization of basic views on international law generally has been apparent. The South West Africa cases reflected this polarization in the Court and were the major cause of the pre-occupation of Afro-Asian states with the Court's membership. The last election demonstrates that these states, aware of the importance of this development, were determined to ensure that future Courts would reflect fully the polarization which has occurred.

The divergence in fundamental views of international law is directly related to developments in international society and, especially, the emergence of the General Assembly as a universal forum. The General Assembly was particularly concerned with human rights and colonialism, with South African policies in relation to South West Africa providing the major focus of attention. Much has been written on the South West Africa Cases, and it is not proposed to consider them here. ${ }^{36}$ Some general observations must be made, however, because they provide an excellent example of the relationship between political and social developments in the international community and the emergence of a meaningful "new" international law.

Until the 1966 judgment it could be said that the International Court's pronouncements on South West Africa, within its general conservative tradition, reflected the increasing concern of the international community with such issues as human rights and individual freedoms. The Court in 1966 reversed this trend. The Afro-Asian States agreed-as did some commentator ${ }^{37}$ - that the most plausible explanation for the 1966 judgment was that the effective majority

36. Following advisory opinions from the ICJ in 1950,1955 and 1956, which confirmed that S.W. Africa was still a territory under the League of Nations Mandate created in 1920, and that South Africa's obligations under the Mandate (including the duty to submit to U.N. supervision of her administration of S.W. Africa) continued, Ethiopia and Liberia applied to the ICJ to confirm the findings of its advisory opinion in a binding judgment, and to hold further that South Africa had violated its obligations by, inter alia, introducing apartheid into S.W. Africa, establishing military bases there and refusing to submit reports or transmit petitions from inhabitants to the U.N. The Court, in the Preliminary Objections Phase, held, by 8 votes to 7 votes, that it had jurisdiction to adjudicate upon the merits of the dispute, [1962] I.C.J. 319, 347. In the Second Phase, [1966] I.C.J. 6, the Court held (by the President casting his vote) that neither Ethiopia nor Liberia had a sufficient "legal interest" in the subject matter of their claims, and the Court was not, therefore, able to decide the merits of the case.

37. See, e.g., Falk, The South West Africa Cases: An Appraisal, 21 INT'L Organisation 1 (1967); Reisman, Revision of the South West Africa Cases, 7 VA. J. INT'L L. 1 (1966).. 
wished simply to reverse the legal assumptions accompanying the 1962 judgment and that the membership of the Court in 1966 was affected by fortuitous events. From a brief analysis of the membership situation, it is difficult to avoid the conclusion that the decision would have been in favor of Ethiopia and Liberia in "normal" circumstances. Judge Khan, now President, was disqualified from sitting. ${ }^{38}$ There was, and is, no doubt, however, that Judge Khan's personal views on racial discrimination and on the dynamic role of the Court in international law made it unlikely that he would have subscribed to the conservative view which prevailed in 1966. Judge Badawi of the U.A.R., who had concurred in the judgment of 1962 dismissing South Africa's preliminary objections, died pendente lite and his replacement, Judge Ammoun of Lebanon, did not participate. Judge Bustamante of Peru was incapacitated by illness. In view of his strong separate opinion ${ }^{39}$ in favor of the applicants in 1962, his absence must be regarded as a major cause of the majority in 1962 becoming a minority in 1966. The decision in 1966 resulted from the casting of a vote by the President, Sir Percy Spender of Australia, a leading member of the "conservative" faction. If the then Vice President, Wellington Koo, had bcen President, the decisive vote, if required at all, would surely have been cast the other way. ${ }^{40}$

The immediate reaction of the Afro-Asian bloc and the determined efforts subsequently to secure a Court more sympathetic to new international law views is understandable. On a more detached level, the 1966 judgment must be regarded as marking a decisive juncture in the life of the Court. The majority decision was based on the traditional positivistic view of international law while the dissenting opinions emphasized its teleological character and the function of the Court in developing law to match developments in international society ${ }^{41}$ While the present system of triennial elections ensures a rapid turnover in membership of the Court, as long as present voting proce-

38. The official statement on his disqualification does not disclose the grounds, [1965] I.C.J. 9. Judge Khan was a prominent member of the Pakistani delegation at the U.N. when Pakistan voted against South Africa on S.W. African affairs, and had been nominated as a judge ad hoc by Ethiopia and Liberia before his election to the Court. These factors presumably prompted the President, Sir Percy Spender, to inform him that it would be "unwise, if not improper" for him to sit. See also Morley, Relative Incompatibility of Functions, 19 INT'L \& CoMP. L.Q. 316, $326(1970$ ) (and sourees quoted in id. n.54).

39. [1962] I.C.J. 349.

40. Vice President Koo delivered a dissenting opinion, [1966] I.C.J. 214.

41. See generally Falk, 21 INT'L ORGanisation, supra note 37; Reisman, 7 VA. J. INT'L L., supra note 37. 
dures and patterns of voting in the United Nations remain unchanged, it is certain that the membership of future Courts will fully reflect Third World influence. In appropriate cases, therefore, new international law views may be expected to come to the fore in decisions of the Court.

The latest pronouncement by the Court appears to support this contention. In the Advisory Opinion on the Consequences for States of the Continued Presence of South Africa in Namibia (South West Africa), delivered on June $21,1971,{ }^{42}$ the Court held: first, by a 13 to 2 vote, that the continued presence of South Africa in Namibia being illegal, South Africa is under obligation to withdraw its administration from Namibia immediately and thus put an end to its occupation of the Territory; second, by 11 to 4 , that states-members of the United Nations are under obligation to recognize the illegality of South Africa's presence in Namibia, and the invalidity of its acts on behalf of or concerning Namibia, and to refrain from any acts and in particular any dealings with the Government of South Africa implying recognition of the legality of, or lending support or assistance to, such presence and administration; and, finally, by the same vote, that it is incumbent upon states which are not members of the United Nations to give assistance to the United Nations in the action which has been taken with regard to Namibia. ${ }^{43}$

The Court had earlier rejected objections raised by South Africa against the participation in the proceedings of three members of the Court. ${ }^{44}$ On February 8,1971, when the public sittings opened, the President dealt with another contention of South Africa that, even if the Court had competence to deliver the opinion, which South Africa denied, it should nevertheless, as a matter of judicial propriety, refuse to give the requested opinion on account of political pressure to which, it was contended, the Court had been or might be subjected. The President declared that it would not be proper for the Court to entertain those observations, bearing as they did on the very nature of the Court as the principal judicial organ of the United Nations, an organ which in that capacity acts only on the basis of law, independently of all outside influences or interventions. ${ }^{45}$ These objections directly im-

\footnotetext{
42. [1971] I.C.J. 16.

43. Id. at 58 .

44. The President, Sir Muhammad Zafrulla Khan, Judge Padilla Nervo, and Judge Morozov. The objections to all three were similar to those advanced against Judge Khan in the S.W. Africa Cases (Second Phase); see note 38 supra.

45. [1971] I.C.J. at 23.
} 
pugned the integrity of the Court, and the very fact that they were raised at all should concern the Court and the General Assembly more than the proposal to amend article $22 .{ }^{46}$

The conception of the Court as an organ somehow entirely above politics is naive. The Court is, as the President said, the principal judicial organ of the United Nations, a very political body. What is now urgently required is a clarification of the relationship between the Court and the other organs of the U.N.

The Advisory Opinion will no doubt reeeive detailed analysis and discussion in due course, but one observation which is relevant to this article may be made immediately. The Court, in dealing with general objections to the General Assembly resolution terminating the South West Africa Mandate (2145 XXI) and the specific contention that the Assembly had wrongfully assumed judicial functions in this matter, said:

This is not a finding on facts, but the formulation of a legal situation. For it would not be correct to assume that, because the General Assembly is in principle vested with recommendatory powers, it is debarred from adopting in specific cases within the framework of its competence, resolutions which make determinations or have operative design. ${ }^{47}$

It is submitted that this appears to represent for the first time the acceptance by the Court, as distinct from individual judges, of the new international law view of the collectivistic generation of customary international law. The phrase "formulating a legal situation" expresses perfectly the process whereby the General Assembly manifests the juridical conscience of the international community.

The formulation of the legal situation in relation to South West Africa was an easy task. The underlying issue, racial discrimination, was one in which it was possible to demonstrate near-unanimity in the juridical conscienee of the nations. The General Assembly and the Security Council, as well as other international bodies, by overwhelming majorities had condemned racial discrimination on numerous oc-

46. This is of course not the first time that the Court has been accused of partiality and the judges have many times been suspected of following the political views of their own governments. For a full discussion and refutation of these allegations and an earlier full examination of political factors and the Court, see Anand, The Intcrnational Court of Justice and Impartiality Between Nations, 12 IND1AN Y.B. INT'L AFF. (1963). Such allegations have generally been made by commentators on individual decisions rather than by parties in the course of proceedings, and as Anand said, governments on the losing side generally refrain from impugning the integrity of the Court's motives.

47. [1971] I.C.J. at 50 (emphasis added). 
casions. ${ }^{48}$ The Court in an advisory opinion in 1950 had confirmed the international status of South West Africa, as well as South Africa's obligation to submit to the supervision of the General Assembly in its administration of the territory ${ }^{49}$ If the minority of the Court had prevailed in 1966, it is clear that the judgment would have emphasized the existence of an objective international standard or criterion as an aid to interpretation of the mandate. Such a standard could be utilized to measure objectively whether the practice of apartheid in the mandated territory of South West Africa was a violation of the mandatory's obligation "to promote to the utmost the material and moral well-being and the social progress of the inhabitants of the territory." ${ }_{50}$ The juridical conscience of the nations, or what Judge Tanaka called the collectivistic generation of international customary law, ${ }^{51}$ would have been accepted as a basis for decision. Five years of further international social and political development, and a Court whose composition fully reflected that development, ensured its acceptance in' 1971 .

The degree of unanimity which exists in the international community on the subject of racial discrimination hardly exists on any other subject. Even if one accepts Judge Alvarez's view that the International Court is the "most authoritative organ for the expression of the juridical conscience," such conscience on the question before it. That is the major problem confronting the Court and the advocates of new international law.

Although great principles may originate in the legal conscience of peoples, they must, to have value, said Judge Alvarez, be expressed by authorized bodies like diplomatic assemblies, the International Law Commission, or the International Court. ${ }^{53}$ The U.N. General Assembly is accorded a pre-eminent place among these bodies. ${ }^{54} \mathrm{Op}$ ponents of this view point to the obvious political character of many resolutions of the General Assembly. ${ }^{55}$ Where resolutions conflict with interests which were created or developed under the protection of

48. For an enumeration of the various resolutions, declarations and conventions, see S.IV. Africa Cases (Second Phase), [1966] I.C.J. 6. 292-93 (dissenting opinion of Tanaka, J.).

49. Advisory Opinion on International Status of S.W. Africa, [1950] I.C.J. 128.

50. [1966] I.C.J. at 433 (dissenting opinion of Jessup, J.).

5I. Id. at 294.

52. [1948] I.C.J. 69.

53. [195I] I.C.J. 148-49.

54. [1954] I.C.J. 71.

55. See, e.g.. Cheng, 1954 Y.B. WORLD AfF., supra note 27. 
traditional international law, their legislative character is strongly denied. Indeed if one were to search for the existence of a juridical conscience in the General Assembly on many of the current issues in international law, one would search in vain, thereby giving justification for the assessment that " $[t]$ here simply is not an advanced international society, no subordination of particular interests to common values, no sense of solidarity." ${ }^{56}$ If this essential basis of the new international law does not exist, how can the International Court respond to the necessity for the substitution of a new international law for the system of European origin that at present exists? A simple descent into the political arena of the General Assembly is clearly untenable. The Court on several occasions has stressed that it is not part of its judicial function to submit matters before it to any form of political treatment. ${ }^{57}$ But the Court has also accepted the proposition that international law is influenced by changes in international society $^{58}$ and what is required at the present time is a reconciliation between the positivistic emphasis on individual consent of states in international law and the new international law emphasis on the collective formulation of customary law. An amendment of article 38 could effect this reconciliation.

Article 38 and Individualism and Collectivism in International Customary Law

The Court, in deciding disputes in accordance with international law, is required to apply "international custom as evidence of a general practice accepted as law." ${ }^{59}$ In the orthodox view the essential constitutive requirement of a rule of customary international law is the fact of a constant and uniform practice among states, accompanied by a subjective sense that observance of the practice is obligatory, opinio juris sive necessitatis. ${ }^{60}$ The Court has hitherto adopted a re-

56. Samore, The New International Law of Alejandro Alvarez, 52 AM. J. INT'L L. 4I, 54 (1958).

57. S. RosENNE, supra note 5, at 91.

58. See, e.g., Advisory Opinion on Reparation for Injuries Suffered in the Service of the United Nations, [1949] I.C.J. 174, 178.

59. I.C.J. STAT. art. 38.1.(b).

60. I D. O'CONNELL, INTERNATIONAL LAW 16-17 (1965). 1 L. OPPENHEIM, INTERNATIONAL LAw 26 (8th ed. 1955). For the formulation of the requirements of a customary rule by the International Court, see the Columbian-Peruvian Asylum Case, [1950] I.C.J. 266, 276-77. Some writers deny the necessity for the subjective requirement. See, e.g., GUGGENHEIM, ÉTUDES EN 1.'HONNEUR DE GEORGeS SCELle 1.275-80 (1950). 
strictive interpretation of article 38.1.(b) by emphasizing the necessity for evidence that the particular state in question has accepted an alleged customary rule as law. ${ }^{61}$ Thus, for example, in the Fisheries Case $^{62}$ it was possible for Norway to demonstrate that she was not bound by an alleged rule because she had always opposed it. ${ }^{03}$

On the general question, however, of the Court's obligation to apply "international custom as evidence of a general practice accepted as law" there is clearly scope for the Court to develop international law. The formulation and modification of customary law is an evolutionary matter, ${ }^{64}$ and there have always been areas in international law where it was difficult to distinguish the point where arguments de lege ferenda had ceased, and it was possible to speak of a custom de lege lata. At present, this familiar conflict is often conducted within the "traditional" and "new" international law dichotomy, and it is at this point that the International Court in appropriate cases can and must reconcile "individualism" and "collectivism" in international law. It is at this point also that the essential interrelationship between international law and international politics must be utilized. If the Court is to develop its role in international law, it must adopt a more positive attitude toward the new community source of rules of international law which will require a descent into the political arena. This is not to say that decisions of the Court must henceforth be based on political or ideological considerations. Rosenne expressed the true position:

In thus postulating the existence of a political function, it is not implied that the Court subjects, or ought to subject, the matters submitted to it to any form of political treatment and reach its decisions on opportunistic grounds or those of expediency, although that is not to say that the members of the International Court, as the judges of any domestic court, are expected to remain indifferent to prevailing trends and requirements of the Society which has charged them with judicial functions. ${ }^{65}$

The political function which the Court must fulfill in the era of new international law is not dissimilar to the political function which municipal courts fulfill in municipal legal systems. It is no doubt largely true that the sentiment of solidarity-the foundation of the

61. Rights of Nationals of the U.S. in Morocco Case, [1952] 1.C.J. 176, 199; Fisheries Case, [1951] I.C.J. 116, 131; Columbian-Peruvian Asylum Case, [1950] 1.C.J. 266, 276.

62. [1951] I.C.J. 116, 131.

63. See 1 G. SCHWARZENBERGER, INTERNATIONAL LAW 41 , 319-23 (3d ed. 1957).

64. D. O'ConNELL, supra note 60, at 20.

65. S. ROSENNE, supra note 5, at 90-91. 
house of new international law that Alvarez built-is absent in contemporary international society. ${ }^{68}$ But there is a substantial element of homogeneity in that society; there has emerged a degree of cooperation to achieve agreed purposes; and there is near-universal agreement on some important basic issues. ${ }^{67}$ The problems in international society-the struggle for economic development by under-developed nations, and the battle for international justice by oppressed groups-are paralleled in the history of municipal legal systems. ${ }^{68}$

Many of these problems can only be solved by international conventions or by existing or new international institutions of a global or regional character. The judicial process, whether in municipal or international law, is not the primary vehicle for major legal or institutional reforms. Judicial decisions do, however, play a vital part in the interpretation and development of existing law, and may provide a primary "law-making" source in important areas where legislation is unsuitable or impracticable. The International Court of Justice cannot exempt itself from fulfilling these functions. The Court, if it is to remain a credible international tribunal, must distill from the political maneuvering and propaganda in organs such as the United Nations the genuine juridical conscience of the nations which has always been the real substratum of international customary law.

As has been observed, ${ }^{69}$ manifestations of juridical conviction occur in all manner of ways, and it is only when formulated by a judge or a jurist that these manifestations become articulate. The task of the Court must henceforth be to formulate rules of international law from the various manifestations of juridical conviction in diplomatic assemblies. "To await their firal and conscious adoption by governmental authorities before deciding that lex ferenda has become lex lata is to impose on international law an unnecessary and frustrating halter." "70

The formulation of new rules of international law by the Court is

66. Samore, 52 AM. J. INT'L L., supra note 56, at 54.

67. The resolutions of the General Assembly, cited above at notes 22-25, provide evidence of this.

68. Examples of the struggle by trade unions to secure legal recognition include the efforts in the U.S. to secure civil rights for Negroes.

69. D. O'CONNELL, supra note 60 , at 21 .

70. Id. 
an established and accepted practice. ${ }^{71}$ This creative function has been exercised within the traditional framework of the generation of customary law by an individualistic process. What is now required is the overt acceptance by the Court of the existence of a new framework - the generation of customary international law by a collectivistic process. The collectivistic process in question is essentially a political process involving the method of parliamentary diplomacy. It is true that much of the law generated in this way is quickly transformed into multilateral conventions. The task of the Court in this event is relatively easy and involves no departure from settled principles of interpretation and application of treaties.

It is also possible to argue ${ }^{72}$ that the Court may apply directly, as international custom, particular "rules" that have emerged from the proceedings of international organizations. But a direct attempt to subsume this situation under article 38.1.(b), "international custom, as evidence of a general practice accepted as law," presents some difficulties. Not the least of these is that states which could demonstrate express rejection of the alleged new rule, by consistent contrary votes or declarations in international assemblies, could presumably rely on previous decisions of the International Court which emphasized the non-applicability of a customary rule against a State which could show consistent opposition to it. ${ }^{73}$

It seems preferable to adopt the indirect and more detached method of abstracting the juridical conscience and to allow the Court to formulate the new rule. Where appropriate, the formulation of the new rule may include the abrogation of an old rule where "the manifestation of juridical conviction" indicates rejection of the old rule.

There is little danger that the Court will fail to distinguish between "instant" customary law born of politically expedient majority resolutions of international organizations and manifestations of genuine juridical conviction. The distinction between isolated resolutions, adopted perhaps by a narrow majority, and a serics of resolutions, adopted unanimously or with minimal opposition, is obviously relevant here and would no doubt be used by the Court in its search for

71. For a convenient summary of the impressive contributions made by the Court toward the clarification and development of international law over a period of 20 years, see Cheng, 1966 Y.B. OF WORLD AFF. 241, 245.

72. See, e.g., S.W. Africa Cases, [1966] I.C.J. 4, 29 1-92 (dissenting opinion of Tanaka, J.).

73. See note 61 supra and accompanying text. 
the juridical conscience of nations. ${ }^{74}$

In performing this task, the Court will have to consider all facets of international society including international politics. It may be necessary to formulate rules primarily in the light of political preferences. ${ }^{75}$ If the function of the International Court is essentially similar to that of municipal courts, the exercise of some political discretion in the decision of cases in international law must be accepted. ${ }^{76}$ To deny such discretion to judges of the International Court in contemporary international law is to ensure the irrelevance of the international community's highest judicial tribunal. Unless, however, the Statute of the Court is amended to incorporate this function of the Court by formally including the collectivistic generation of customary international law in article 38 , critics of the Court and states-parties to cases before it will feel justified in objecting to the Court on grounds of its political partiality and subjection to political pressures.

\section{Summary and Conclusion}

It may well be that the proposed change in the seat of the Court has little meaning. Irrespective of a change in the Court's location, it is submitted that article 38 should be amended to provide unequivocally for the collective generation of customary international law as one of the sources of the law which the Court may apply. The Court can no longer always apply traditional international law, with its origin in the Europe of Grotius, in a near-universal community of states divided into various ideological blocs.

It is an over-simplification to dismiss recent events concerning the Court as "merely" political or to assert that many new states simply reject entirely European based international law. The dissatisfaction of the Third World with some existing concepts and rules is based on

74. Judge Tanaka explained the distinction:

Of course, we cannot admit that individual resolutions, declarations, judgments, decisions, etc., have binding force upon the members of the organization. What is required for customary international law is the repetition of the same practice; accordingly, in this case resolutions, declarations, etc., on the same matter in the same, or diverse, organizations must take place repeatedly. [1966] I.C.J. 4, 292.

75. R. Higgins, The Development of International Law Through the Political Organs of THE UNITED Nations 9 (1963).

76. This involves acceptance of the postulate that municipal courts and judges perform a political function in helping to regulate the social distribution of values. See generally M. Kaplan \& N. Katzenbach, Political Foundations of International Law (1961), cited by R. HiGGINS, supra note 75 , at 8 . 
the reasonable claim that international law must reflect a consensus of the new world community. In some fields "old" international law is incompatible with the new world order. The International Court should explicitly accept this fact and assist in formulating the rules of the new international law which finds its origin in the juridical conscience of the nations of the world.

Unless the Court does so, the very limited number of cases which presently comes before the Court will dwindle to nothing. There is more danger for the Court in a charge of irrelevancy in contemporary international society than in fears that its prestige will be diminished by a descent into politics. Unless it accepts the hazards involved in such descent, it will fail to bridge the gap between old and new international law, and it will have failed in its function as the principal judicial organ of the international community. 